\title{
年齢群におけるテオフィリンクリアランスの違い
}

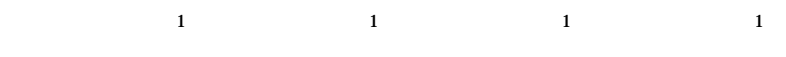 \\ 黑木尚美 ${ }^{2}$, 小藪真紀子 ${ }^{3}$ \\ 国立病院機構福岡病院薬斉科 ${ }^{1}$ \\ 国立病院機構東佐賀病院薬斉科 ${ }^{2}$ \\ 国立病院機構長崎医療センター薬斉科 ${ }^{3}$
}

\section{Age-Related Differences in Theophylline Clearance}

\author{
Kenichi Manabe*1, Naoyuki Murakami ${ }^{1}$, Makoto Tanaka ${ }^{1}$, Yuki Ushio ${ }^{1}$, \\ Naomi Kuroki and Makiko Koyabu ${ }^{3}$ \\ National Hospital Organization Fukuoka Hospital Pharmacy Department ${ }^{1}$ \\ National Hospital Organization Higashisaga- Hospital Pharmacy Department ${ }^{2}$ \\ National Hospital Organization Nagasaki Medical Center Pharmacy Department ${ }^{3}$
}

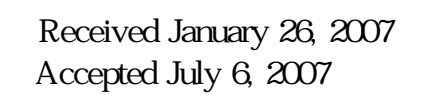

Since it has frequently been observed that high serum levels of theophylline are difficult to control in children, we monitored serum theophylline concentrations in 868 patients, of which 322 received the drug as a continuous infusion. Generally, serum theophylline concentrations vary greatly among individuals and this is considered to be due to differences in clearance.

In this study, we investigated the relationship between age and serum theophylline concentration and theophylline clearance, finding that there was a weak association between dosage and serum concentration in all the age groups, which was not meaningful. Our results also suggested that theophylline clearance in children was greater than that in adolescents and adults, with the clearance in children in the 1-5years (preschool) and 6-8years age ranges being higher than that for pa tients in the 9-12 and 13-53years age ranges. Our results suggested that the dosage should be determined based on theophylline clearance calculated with respect to age instead of on the standard value of $0.04(\mathrm{~L} / \mathrm{kg} / \mathrm{hr})$ given in textbooks.

Key words — theophylline, clearance, age, serum concentration

緒言

喘息治療ガイドラインの改訂11によりテオフィリンの 位置づけに変更が生じたが, 小児科入院の患児はRTC (round the clock)療法年にに基づくテオフィリンの持続点 滴や内服を受けることが多い，国立病院機構福岡病院に おいて，2005年 4 月から 2006 年 9 月末日までのテオ フィリン血中濃度測定件数は 868 件にも上っている. また，成人に比べて小児，学童児では発作のコントロー ルがうまくいかず, 投与量の変更を余儀なくされること がしばしば見られ，弚の都度テオフィリン血中濃度を測 定している．弚こで今回，この測定結果を分析し，年齢
群によるテオフィリンクリアランスの差を見いだしたの で報告する．

\section{方法}

868 件の測定件数のうち, パラメーター算出可能な持 続点滴のデータを分析対象とし，テオフィリンの代謝に 影響を与える併用薬物か記載されているデータは除外し た .また，同一患児でも 6 力月後の再入院や投与量が異 なるものは別データとして取り扱った .さらに，入院初 期の測定結果は，定常状態に達していないと考えられる ために除外した . 血中濃度は蛍光偏向免疫法(FPIA 法) で測定し，薬物クリアランスは下記の式によって算出し 
た . また統計処理は，一元配置分散分析と Tukey 法を 用いて検定した。

薬物クリアランス $=($ 塩係数 $) \times($ 生物学的利用率 $) \times($ 投 与量/投与間隔) $\div$ (定常状態の血中濃度)

投与量 $/$ 投与間隔 $=\mathrm{mg} / \mathrm{kg} / \mathrm{hr}$

テオフィリンの塩係数は 0.8 生物学的利用率は 1.0 上記の方法に基づくデータ 322 件について，投与量と 血中濃度の関係および年齢別の投与量と血中濃度の関 係，さらには年齢とテオフィリンクリアランスの関係に ついて検討した .

結果

テオフィリンの投与量と血中濃度の関係は図 1 のとお りであった . 血中濃度は弱いながらも投与量に比例 $(\mathrm{P}<$ 0.005)していたが, グラフが示すように個体間の差が大 きく見られた . 乥こでこの原因を検討するために，まず 年齢別の投与量と血中濃度の関係を調べた . 1 6 歳の 乳幼児, 7 12 歳の学童, 13〜 53 歳の群に分けて血中濃 度と投与量の関係をみたものが表 1 である . 成人に比し て乳幼児期および学童期の患児にやや強い相関が見ら れ，成人になると相関か溺くなる傾向を示していたが，

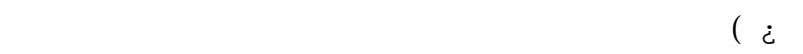
0.05).

次にテオフィリンクリアランスに注目し , 年齢毎のク リアランスを算出した(表 2).クリアランスを検討する

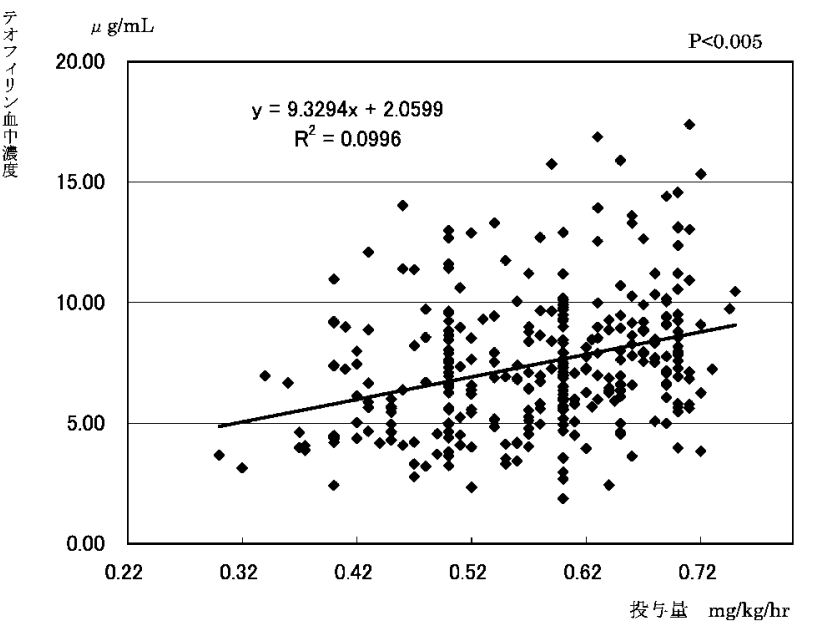

図 1 . 投与量と血中濃度
上で乳幼児, 学童, 13 歳以上を考え, 最近の身体の発 達を考慮して 1〜5歳, 6〜8歳, 9〜12歳, 13〜 53歳の 4つの群における光れ光れのクリアランス平均值を検討 した(表 3). 1 歳以下は例数が 2 例であるために, 検討 対象から除外した . 各群におけるテオフィリンクリアラ ンスの平均值をみると,1〜 5歳では $0.0717 \pm 0.022(\mathrm{~L} / \mathrm{kg} /$ hr) , 6 8歳では 0.0811+0.0307(L/kg/hr)，9〜12歳で

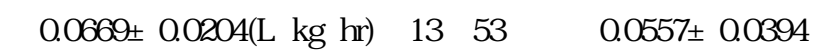
$(\mathrm{L} / \mathrm{kg} / \mathrm{hr})$ であった . これら 4 群について一元配置の分 散分析を行うと，4群間に平均值の差が認められた $(\mathrm{P}=$ 0.000176). 弚こでTukey 法で群検定を行った結果(表 4), 6〜8歳は 9〜12歳および 13〜53歳と比してクリアラン スが大きく $(P=0.005, P=0.001), 1$ 5 歳は 13〜53歳 と比してクリアランスが大きく $(P=0.001)$ なっていた .

\section{考察}

薬物の脂溶性や蛋白結合率，および排泄速度は血中濃 度に影響を与える゙)とされ，理想体重の平均テオフィリ ンクリアランスは $0.04 \mathrm{~L} / \mathrm{hr} / \mathrm{kg}^{4)}$ とテキストに記されて いる . テオフィリンの場合 , 多くの文献で血中濃度にお ける個体間のばらつきが報告5.6)されており，弚の要因と してテオフィリンクリアランスの違いが指摘》されてい る.弚こでテオフィリンクリアランスについてPub Med およびメディカルオンラインにて検索を行うと，テオ フィリンクリアランスと年齢との関係を論じたものが , 2報見出された .一つは 1982年の M.J. Gardner らの報 告8であり，他は 1994 年の上野らの報告9であった .

結果に示したように，1５歳および6〜8歳の小児で は 13〜53歳に比べて大きなクリアランス值を有し, 若 年者に比して年齢か増えるとともにクリアランスが減少 するという M.J. Gardnerらの報告内容と一致してい た . 上野らの報告においても 2 歳未満については 2 歳以 上の小児とテオフィリンクリアランス值が異なるとさ れ，投与量の設定を年齢に応じたクリアランス值を用い るべきであるとしている．つまり，テオフィリンクリア ランス值はテキストに示される平均値で投与量を設定す るのではなく，年齢に応じたクリアランス値の設定が必 要であると考えられる.一方, 上野らの報告の中では 2 歳以上にテオフィリンクリアランスの変化は見られない とされており，われわれの検討結果と異なるものであっ

表 1. 年齢群毎の投与量と血中濃度の相関

\begin{tabular}{|l|c|c|cl|}
\hline & $X$ 值の係数 & 切片 & \multicolumn{2}{|c|}{$\mathrm{R}^{2}$} \\
\hline $1 \sim 6$ 歳 & 9.8722 & 1.3001 & 0.1417 & $(\mathrm{p}<0.005)$ \\
\hline $7 \sim 12$ 歳 & 11.1771 & 0.7598 & 0.1117 & $(\mathrm{P}<0.005)$ \\
\hline 13 歳 $\sim 53$ 歳 & 11.9416 & 3.0375 & 0.1011 & $(\mathrm{p}=0.06)$ \\
\hline
\end{tabular}


表 2 . 年齢別のテオフィリンクリアランス $(\mathrm{L} / \mathrm{kg} / \mathrm{hr})$

\begin{tabular}{l|c|c|c}
\hline 年齢 & 例数 & クリアランス $(\mathrm{L} / \mathrm{kg} \cdot \mathrm{hr})$ & $\mathrm{n}$ \\
\hline 1歳 & 37 & $0.0719 \pm 0.0248$ & 28 \\
2歳 & 28 & $0.0755 \pm 0.0297$ & 28 \\
3歳 & 35 & $0.0703 \pm 0.0293$ & 32 \\
4歳 & 34 & $0.0703 \pm 0.0247$ & 32 \\
5 歳 & 25 & $0.0707 \pm 0.0228$ & 23 \\
6歳 & 26 & $0.0865 \pm 0.0372$ & 23 \\
7歳 & 21 & $0.0749 \pm 0.0208$ & 19 \\
8歳 & 13 & $0.0803 \pm 0.0299$ & 13 \\
9歳 & 9 & $0.0684 \pm 0.0373$ & 9 \\
10歳 & 17 & $0.0639 \pm 0.0203$ & 15 \\
11歳 & 21 & $0.0650 \pm 0.0119$ & 15 \\
12歳 & 16 & $0.0718 \pm 0.0178$ & 14 \\
13歳 53歳 & 38 & $0.0557 \pm 0.0394$ & 32 \\
\hline \multicolumn{4}{|c}{$\mathrm{n}:$ 㞻芹数 }
\end{tabular}

表 3. 各年齢群におけるテオフィリン クリアランス $(\mathrm{L} / \mathrm{kg} / \mathrm{hr})$

\begin{tabular}{l|l|c}
\hline 年齢群 & $\begin{array}{l}\text { クリアランス } \\
(\mathrm{L} / \mathrm{kg} \cdot \mathrm{hr})\end{array}$ & 例数 \\
\hline $1 \sim 5$ 歳 & $0.0717 \pm 0.0262$ & 159 \\
\hline $6 \sim 8$ 歳 & $0.0811 \pm 0.0307$ & 60 \\
\hline $9 \sim 12$ 歳 & $0.0669 \pm 0.0204$ & 63 \\
\hline 13 53歳 & $0.0557 \pm 0.0394$ & 38 \\
\hline
\end{tabular}

表 4. 分散分析および検定結果

\begin{tabular}{|c|c|c|c|c|c|}
\hline グループ & 標本数 & 平均 & 分散 & & \\
\hline 1 5歳 & 159 & 0.071665 & 0.000686 & & \\
\hline $6 \sim 8$ 歳 & 60 & 0.081101 & 0.000943 & & \\
\hline 9 12歳 & 63 & 0.066911 & 0.000418 & $* *$ & *** \\
\hline $13 \sim 53$ 歲 & 38 & 0.055719 & 0.00155 & & \\
\hline
\end{tabular}

\begin{tabular}{cccc}
\hline 変動要因 & 分散 & $\begin{array}{c}\text { 観測され } \\
\text { た分散比 }\end{array}$ & P-值 \\
\hline グループ間 & 0.005356 & 6.846189 & 0.000176 \\
グループ内 & 0.000782 & & \\
\hline
\end{tabular}

た .これは上野らの報告における対象が14歳までであ り，年齡区分の違いと $\mathrm{t}$ 検定の結果によるものであると 考えられる．今回の結果も含めて，いずれの報告におい てもテオフィリンクリアランスは, テキストに記される $0.04 \mathrm{~L} / \mathrm{hr} / \mathrm{kg}$ ではなく年齢に応じた值を設定することに より，投与量の設定がより適切なものになると考えられ る.われわれのところでは, テオフィリン解析ソフトと してテオプレディクトーIIII ${ }^{\mathrm{T} 10)}$ を利用しているが，本ソ フトは年齢毎のクリアランス值が組み込まれており，わ れわれの結果と近い数值か設定されているために兴の利 用価値を確認することもできた .

今回のわれわれの検討において年齢群を一般的な乳幼 児，小児，学童の見方に併せて分類したが，これについ てはもっと明確な方法が必要になってくると考えられ
る.われわれが利用しているテオプレディクトテオプレ ディクト $11{ }^{10}$ における母集団パラメーターにおいても， 0 0.5 歳, 0.5 1歳, 1 2 歳, 2〜9歳, 9〜17歳, 17〜 60 歳, 60 歳以上の 7 群に分類され, 产れ艺れにクリア ランス值か設定 ${ }^{10}$ されているが，各群の明確な分類根拠 は示されていない．上野らの報告においても年龄群の設 定根拠は不明であった．したがって，年齢群での検討で はなく各年齢における十分なデー夕数を確保した上で， テオフィリンクリアランスと年齢との相関を見る必要が あると考えている .

\section{引用文献}

1）日本小児アレルギー学会“, 小児気管支治療管理ガイ ドライン 2005”，森川昭廣，西間三馨監修，協和企 画，東京，2005, pp.66-137.

2) M.M. Weinberger, E.A. Bronsky, Evaluation of oral bronchodilator therapy in asthmatic children. Bronchodilators in asthmatic children, The journal of pediatrics, 84, 421-427 (1974).

3) G. Hambleton, M. Weinberger, J. Taylor, M. Cava naugh, E. Ginchansky, S. Godfrey, M. Tooley, T. Bell, S. Greenberg, Comparison of cromoglycate (cromolyn) and theophylline in controlling symptoms of chronic asthma. A collaborative study, Lancet, Feb, 19, 381385 (1977).

4) M.E. winter, 樋口駿 監訳“, ウィンターの臨床薬 物動態学の基礎”,テクノミクス，東京，1999, p.328.

5）西間三馨，根本紀夫，和田博泰，山口淑子，村上理 恵子, 杉本日出雄, 椿俊和, 西牟田敏之, 関根邦夫, 渡辺博子, 神谷斉, 内田幸憲，駒田幹彦，平尾敏男， 細井進，堀内康生，渡辺毅敏，西川清，浜口武士， 教正院靖子，小田嶋博，宮島一郎，久田直樹，気管 支喘息患児を対象としたテオフィリン徐放性シロッ プ斉の血中動態の検討，基礎と臨床，25, 1431-1439 (1991).

6) 杉本日出雄, 七条孝三郎, 飯倉洋治, 秋本憲一, 気 管支喘息患児における MCl-8019 DS の薬物体内動 態の検討 ，小巟科臨床，47, 557-566 (1994).

7) E. Ginchansky, M. Weinberger, Relationship of theophylline clearance to oral dosage in children with chronic asthma, The journal of pediatrics, 91, 655-660 (1977).

8) M.J. Gardner, W.J. Jusko, Effect of age and sex on theophylline clearance in young subjects, Pediatric Pharmacology, 2, 157-169 (1982).

9)上野和行, 姜英普, 植月重介, 多田博史, 乳幼児に おけるテオフィリンクリアランスに及ぼす年齢の影 響，および投与指針の検討，病院薬学，20, 497-501 (1994).

10) 東京大学医学部附属病院薬剂部監修“, THEOPREDICT-III for Windowsリファリンス マニュアル”， 三菱化学, 東京, 2003, pp.19-20. 